\title{
Managing Digital Contention in China
}

\author{
Dr Ying Miao \\ Lecturer, Department of Politics and International Relations \\ Aston University, Birmingham, UK \\ B4 7ET \\ y.miao2@aston.ac.uk \\ +44(0)1212045028
}

\begin{abstract}
As the digital age expands and evolves, the challenge of digital governance has become greater. This paper explores new developments in cyber content management strategies in China.

In particular, this paper highlights the rise of participatory, peer-to-peer censoring practices, where users are incentivised to report on each other through offering of special privileges and monetary rewards. This paper then goes on to examine how the People's Daily have responded to the contentious events in the top 20 public opinion incidents of 2016, to illustrate how official media uses different types of management strategies to mediate and demobilise contention, on top of information containment strategies such as censorship. Finally, I discuss briefly the creation of a Digital United Front which seeks to incorporate social influencers and cyber elites into mainstream political institutions such as the CPPCC.
\end{abstract}

Not only do these strategies further undermine the formation of a political locus opposite the state, they continue to subsume previously oppositional narratives into grander narratives of stability, rationality, and national progress. Online political participation in Chinese cyberspace must seek further paternalistic protection from Party authorities, often in forms of socio-moral grievances, in order to legitimise their contention. Although this strengthens the Party-state's claim to legitimacy, ultimately this weakens the emergence of civil society in China as the only form of contention that can survive is those that are legitimised by the Party-state, and the political space oppositional to the state remain closed off. 


\section{Introduction}

In an increasingly digital age, scholars have been particularly focused on the emancipatory potential of the Internet, democratic or otherwise (Zheng 2007; 2009; Meng 2010), and its ability to foster a power shift in authoritarian societies such as China (Xiao 2011). In the first decade of the 2000s, scholars made optimistic notes on how the development of the Chinese Internet showed a 'deeply contentious space' and 'strong aspirations for a more just and democratic society', venturing that cyber dissent might play a significant role in China's democratisation, however far down the line (Chase and Mulvenon 2002; 2009). As China expanded its cyber governance efforts, scholars have argued that the Chinese government increasingly sees the cyberspace as an outlet for 'the voice of the public', allowing officials to identify and tackle grievances before they can develop into protest and dissent (Shirk 2011). While the Internet has diminished the Chinese Communist Party (CCP)'s capacity to set the public agenda (Esarey and Xiao 2011), digital tools have also been utilised by the Party to elicit, respond to and direct public opinion (MacKinnon 2011; He and Warren 2011), thus having a positive effect in widening political participation. This has led some to believe that pluralism in the form of online deliberations might be considered a 'foundational condition for a more interactive and liberalised political order rooted in greater public deliberation and societal feedback'(Lewis 2013).

In the last decade, digital and technological tools has been rapidly deployed in increasingly wider aspects of socioeconomic life worldwide(Schlæger 2013), and China is no exception. However, while the role of technology has been lauded in social movements such as the Arab Spring, researchers argue that for China, the CCP has already mastered the technology to the extent that the technology serves as an authoritarian consolidation tool, in that China has already become a 'networked authoritarian regime' (MacKinnon 2011; Tsai 2016). Indeed, the Internet has become particularly relevant to discussions on how the CCP might seek to renew its efforts on propaganda, public opinion management and social management (Brady 2009; Pieke 2012; Shambaugh 2007).

In recent years, Internet usage in China has continued to grow rapidly and the number of netizens have nearly tripled from 253 million in 2008 to 772 million in 2017, with an Internet coverage of 55.8\%. Much has happened during this time. Google left China in 2010, then slowly foreign social media platforms and sources of information began to disappear in Chinese cyberspace one by one: Twitter, Tumblr, Instagram, New York Times, Wall Street Journal, Reddit, just to name a few. The Chinese state deployed proactive and varied strategies for Internet governance: dedicated offices and tactical teams were established, 
censorship tightened, and the technological barrier for circumventing censorship through methods such as Virtual Private Networks (VPN) were raised higher and higher. In the last few years in particular, with Xi Jinping's rise to power, venting space for dissenting opinion in Chinese cyberspace has become increasingly narrow.

While censorship and the stifling of information plays a significant part in China's cyber management strategy, there is increasing awareness that the sociopolitical interaction and development in Chinese cyberspace cannot be understood through censorship, or the either/or dichotomy (such as authoritarianism vs democracy, state vs netizens) alone (G. Yang 2014). The proactive strategies taken by the CCP in trying to control and manage online narratives and public discourse means that the cyberspace also serves as a 'repertoire of contention', which, as Tilly defines it, is 'a limited set of routines that are learned, shared, and acted out through a relatively deliberate process of choice' (Tilly 2015). This not only directly affect netizens' behaviour, but also affect their knowledge of how to behave in contentious space, and affect how others, authorities and peers alike, expect them to behave in contentious times (Tarrow 2011). Thus, contesting narratives in the cyberspace is a continuous process of interaction, negotiation and mediation, with both sides shaping the behaviour and management strategies of the other.

The paper focuses specifically on the nuances of new developments in the three major proactive approaches of online content management that has evolved recently. In particular, this paper highlights the rise of participatory, peer-to-peer censoring practices, where users are incentivised to report on each other through offering of special privileges and monetary rewards. This paper then goes on to examine how the People's Daily have responded to the contentious events in the top 20 public opinion incidents of 2016, to illustrate how official media uses different types of management strategies to mediate and demobilise contention, on top of information containment strategies such as censorship. Finally, this paper discusses briefly the recent creation of a Digital United Front, which seeks to incorporate social influencers and cyber elites into mainstream political institutions such as the Chinese People's Political Consultative Conference (CPPCC), and tasking them as ideological and moral watchdogs in the cyberspace. Not only does these strategies further undermines the formation of a political locus opposite the state, they have also led to the subsumption of previously oppositional narratives into grander narratives of stability, rationality, and national progress. Despite Xi's assurances in his Party speeches, the space for consultative or deliberative political participation online continues to narrow. 


\section{Methods}

This paper explores two emerging trends in online content management in China: the growth and normalisation of peer-to-peer censorship, and the specific management strategies of official arbitration of online contention. For the first section, I look at the publicly released data by the China Internet Illegal Reporting Centre, available at $12377 . c o m$. The second section uses data from the People's Daily web archives and the People's Daily Public Opinion Monitoring Office, available at people.com.cn.

\section{Online Content Control in China: An Overview}

Censorship, as a fundamental part of how the CCP manages information flow in an increasingly digitised age, has been an integral part of Internet research on China. With four elements that can shape behaviour in cyberspace - the architecture of the Internet itself, regulations, social norms, and the market (Lessig 2009) — China has largely monitored the Internet by focusing on the first two factors in the past, using a mixture of low-tech and hightech methods (Chase and Mulvenon 2002). The backbone network that the Chinese Internet runs on (the Internet Interconnecting Network) can only be established by governmentapproved agencies and businesses, and they in turn license Internet Service Providers (ISPs). All networks are filtered through international gateways located in Beijing, Shanghai, and Guangzhou (B. Liang and Lu 2010). Network filtering (severing the network when the Great Firewall detects an attempted access to censored websites) are thus the most common technological forms of censorship alongside with search engine filtering, keyword filtering (that prevents posts containing sensitive keywords from being posted) and deletion after post (Bamman and O'Connor 2012).

Information that is prohibited in the Chinese cyberspace falls under nine broad categories, including content that:

(1) is contrary to the basic principles that are laid down in the Constitution, laws, or administration regulations; (2) is seditious to the ruling regime of the state or the system of socialism; (3) subverts state power or sabotages the unity of the state; (4) incites ethnic hostility or racial discrimination, or disrupts racial unity; (5) spreads rumours or disrupts social order; (6) propagates feudal superstitions; disseminates obscenity, pornography, or gambling; incites violence, murder, or terror; instigates others to commit offences; (7) publicly insults or defames others; 
(8) harms the reputation or interests of the state; or (9) has content prohibited by laws or administrative regulations (Chase and Mulvenon 2002)

Despite the numerous regulations and policies in place, one common finding is that the enforcement of China's Internet filtering is inconsistent. Studies show that Internet blocks have come and gone, and the content of blocks also varies from time to time, most likely because of the fact that there is no coherent and consistent decision-making process (Hartford 2000; Sohmen 2001). The responsibility of propaganda and censorship is divided across different ministries, thus the process of censorship is a complex and intricate one ( $\mathrm{Yu} 2009$; Brady 2012). Regional variations in censorship has also been shown, with far West and North regions such as Tibet and Xinjiang experiencing much higher percentage of post deletions compared to the Eastern seaboard region (Wright 2014; Bamman and O'Connor 2012). Nevertheless, through access blockage for foreign websites and content filtering of domestic websites, the Chinese Party-state has a firm grip on managing the Internet through its architecture and regulations. What is relatively less considered is how the Party-state have been increasingly focusing on managing the Internet though influencing social norms and market behaviours, which became increasingly prominent since Xi came to power in 2013.

While the CCP has always attempted to control political content and narratives on the internet, in recent years, the $\mathrm{Xi}$ administration has expanded such control to previously relatively-free areas such as the entertainment sector, citing purification of moral values as its key legitimating reasons. From 2013 onwards, we have seen the re-introduction of 'campaign style', mobilising governance strategies in Internet content management, especially in the treatment of Key Opinion Leaders (the 'Big Vs' on Weibo) who have stepped out of the line (G. Yang 2017). The downfall of key online opinion leaders have paved way for the rise of 'we-media', a new term coined to describe bloggers and microbloggers that self-generate and disseminate content online. In 2017, these were met with similar fates as the Big Vs before them. Paparazzi-style Weibo accounts that generated celebrity gossip were rapidly shut down with the state justifying its actions as 'clearing the cyberspace of inappropriate values'.

Bilibili and Acfun, both video streaming websites that serves as cyber hotspots for youngsters, had large sections of content shut down due to both inappropriate content and copyright concerns. Homosexual content on forums began to be targeted from October 2017, and gay forum boards began shutting down especially on major forums with high traffic such as Tianya. Major social media outlets such as Tencent Wechat, Sina Weibo and Baidu Forums were each given repeated warnings about their laxness in managing 'illegal and inappropriate user-generated content'. In April 2018, four news apps (Today Headlines, Phoenix News, Netease News and Tencent Kuaibao) were suspended from App Store 
downloads for similar poor content management reasons, the length of the ban ranging from 3 days to 3 weeks. Kuaishou, a Vine-like short vlogger site was publicly criticised by China Central Television (CCTV) on air for its 'low cultural value', after which the app changed its front page to showcase political 'main melody' propaganda videos including videos heralding the success of the CCP. Even the People's Daily Public Opinion Monitoring Office noted that 'there is now a visible hand over the online entertainment sector, which used to be free.' (Hua, Canliang, and Pan 2018)

More stringent censorship with temporal sensitivities has also been observed in the last few years. On 25th February 2018, Xi Jinping announced he is going to abolish term limits to the Chinese presidency. The news was received explosively in Chinese cyberspace and in the following days social media users experienced a kind of zero-tolerance censorship usually reserved for known political dissenters: on Weibo, users who spoke out against the decision or reblogged any related content were banned from accessing their account, and the most fervent disagreers had their accounts completely removed. The keyword "gaixian" or 'changing the constitution' rendered no results in any of the social media search engines. Both and Weibo and Douban (a site that hosts discussion groups) removed the ability to track trending topics in order to avoid political complications during the National Congress that took place that week. The more content heavy Zhihu, a quora-esque Q\&A website, had its app removed from the app stores across all platforms for 7 days during this period, due to "its ineffectual management, and dissemination of illegal information". While its website remained accessible, it was heavily censored and according to Zhihu's own report, in the week between 22nd February and 28 February, 37,770 posts were removed due to being politically sensitive, $37.68 \%$ increase from the week before (Zhihu 2018).

Despite more stringent controls, the continuing spread of the Internet means top-down content monitoring and deletion will become increasingly inefficient. As a result, in the last few years there has been a proliferation of crowdsourced monitoring and reporting approaches that has had a significant impact on how netizens negotiate and respond to contention online.

\section{Peer-to-Peer Censorship: Growth and Normalisation}

In order to maintain the equilibrium between expansion of the Internet and monitor and control the anarchistic information overflow it inevitably brings, the party-state both mobilises its own resources and co-opts the support of voluntary or involuntary collaborators 
(Wacker 2003). Since the 2000s, the Party-state have made self-regulation a priority for online content control, and exerted pressure on nonstate sectors to increase policing power on their behalf(Cheung 2005). A domestic self-discipline mechanism was established in 2002 through the issuing of a "Public Pledge on Self-Discipline for the China Internet Industry", which resulted in more sweeping censor mechanisms as many Internet platforms and businesses decided to play safe when faced with broad and vague regulations (Endeshaw 2004; Sohmen 2001).

In addition, China Internet Illegal Reporting Centre (12377) was launched in 2005 and put under the direct supervision of The Central Cyberspace Affairs Commission. To incentivise users to report 'illegal and harmful content' online, discretionary cash rewards were offered from 2014 onwards (Graph 1). As a result, the use of grassroot reporting of illegal activities has particularly gained prominence in the last few years, with 5.7 million illegal posts reported in February 2018, 88.6\% of which coming from major websites such as Sohu, Baidu, and Sina. Out of these, Sina received most number of reported cases: upwards of 1.8 million (China Internet Illegal Reporting Centre 2018). Despite the reward programme being halted in 2018, the number of posts reported each month has only suffered a momentary decline, and indeed resumed a fast pace of growth in recent months. The numbers suggest that a reporting culture can be said to have been established online. 


\section{No. of posts reported as 'illegal' to the Internet \\ Reporting Centre \\ (http://www.12377.cn/)}

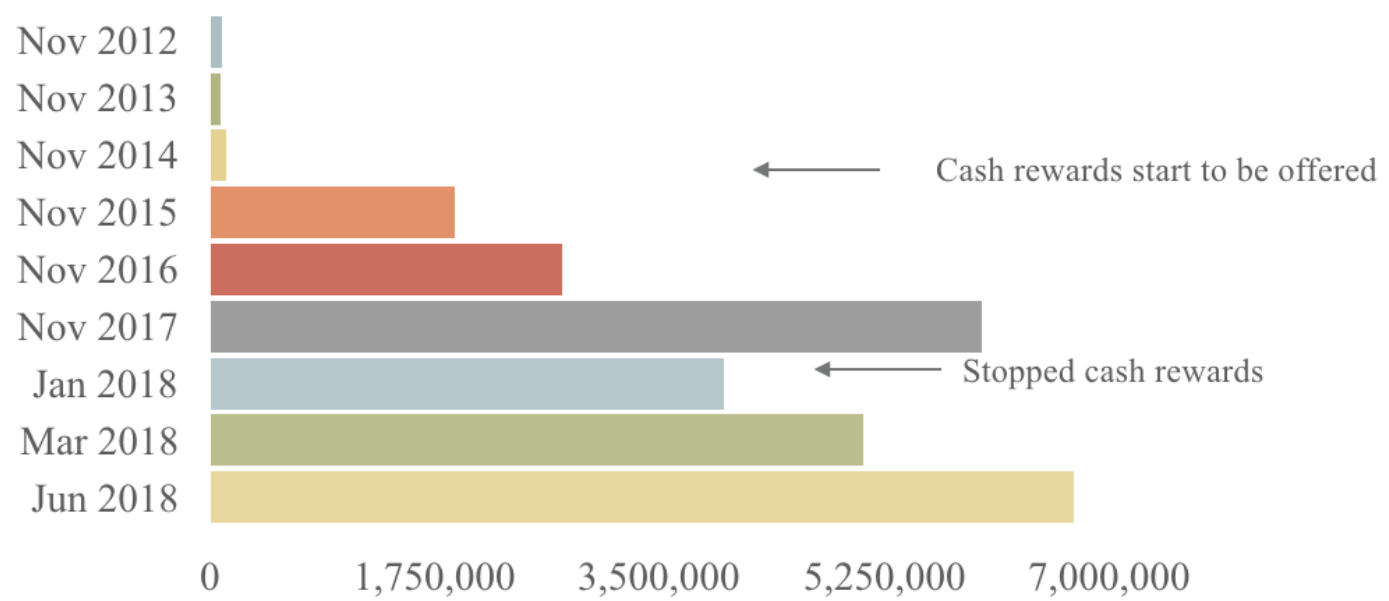

Figure 1 Increase in number of posts reported by netizens (2012-2018)

On 27th September 2017, Weibo announced that they, under the directive of the Beijing Cyber Administration Office, are recruiting 1,000 'Weibo community supervisors', who would report "illegal, pornographic and harmful" information on Weibo to the platform administrators. Successful applicants would receive perks such as 200 yuan per month to subsidise their broadband fees, free access to premium Weibo features, and a special orange coloured VIP status symbol next to their username. Each Weibo supervisor is required to report at least 200 illegal posts a month, and those who report the most number of illegal posts could win a range of prizes including iPhones, Apple products and laptops (Sina Weibo 2017). According to Sina's statistics, 1.56 million illegal (pornographic) posts were reported by 810 active Weibo supervisors in the month of February in 2018, where the top 20 'performers' reported an average of 67,000 posts per person in that month (Sina Weibo 2018). To put it in perspective, assuming the supervisors worked 8 hour days with no breaks, one post was reported every twenty seconds.

Weibo is not alone in the recruitment of human censors. The Cyber Administration Commission published the Management Rules of Internet Group Services in October 2017, which set out the responsibility of group creators and owners on Wechat and QQ. There are also attempts to control and monitor Internet group activities locally: any resident of Xi'an 
with more than 30,000 Weibo or Wechat followers, for example, must register with the local authorities (Hua, Canliang, and Pan 2018). These moves are a part of a wider campaign of 'Self-Discipline Officers' launched by the Beijing Internet Association (BIA), which is under the direct supervision of the Ministry of Propaganda. In year of 2014, BIA recorded that 652 Self-Discipline Officers operated in 21 web domains, reporting half a million illegal posts, including 70,085 'politically harmful' posts, amounting to $12.85 \%$ of total deletions (Beijing Internet Association 2015).

Crowd-sourced monitoring and reporting also played a big part in Xi's anti-corruption drive: cadres who spend lavishly and abuse their power risk being exposed on social media and trigger an investigation by the the Central Commission for Discipline Inspection (CCDI). This 'mass supervision' tactic recalls the mass-line mobilisation strategies employed in the Mao era, which promoted direct interaction between the state and society (Tang 2016; Andreas and Dong 2017). In April 2018, for example, a leaked Wechat screenshot was made viral on Weibo, recording a conversation between the wife of Guang'an's Deputy Party Secretary Yan Chunfeng and her child's nursery teacher. The teacher accidentally posted a complaint of her child's inappropriate behaviour in a shared Wechat group containing the mother, and the mother retaliated by demanding “apologise now or I will tell your nursery's CEO to come to me and explain the way you treat Party Secretary Yan's kid!” Later in the conversation, she boasted about her ability to immediately remove the teacher from the nursery employment roster. In a separate screenshot, she also admitted her child have received special treatment in being enrolled in a highly sought after school ahead of its official recruiting schedule, again due to the father's political position. The post gained a wide following on Weibo and a few weeks later, an official announcement was made that CCDI was launching an investigation into Yan Chunfeng, to much celebratory response. Whether this is an orchestrated political manoeuvre by Yan's political foes or a genuine post made by a concerned citizen is unclear: what is evident is that such incidents actually boosts Xi's administration's image when popular demands seems to have been met. The speed and decisiveness with which the Party Central have responded to this incident has further legitimised crowd-sourced monitoring and reporting as an acceptable form of contention, one where grassroot grievances could be aired and responded to. This form of contention, however, risks a populist rupture (Mudde 2017; Espejo 2017; Abts and van Kessel 2015), as the Party Central is seen as the ultimate source of justice who must directly respond to demands from the populace, which weakens popular trust in intermediary institutions such as the media and other governmental and legal institutions. 


\section{Official Arbitration of Online Contention in the Social Media Age}

The CCP has realised the need to have an official online presence early in the expansion of the Internet in China. Projects such as 'Government Online' were initiated as early as 1999 to 'enhance the presence of ministries, administrative units and local government in cyberspace, furthering transparency and accountability by making more information accessible to citizens, and fighting corruption and fraud'(D. L. Yang 2001). As social media began to amass popularity, they became ideological and political battlegrounds. The Party has cracked down on social media opinion leaders, while local government accounts have proliferated as beta-institutions to deal with netizen's grievances (Svensson 2014; Schlæger and Jiang 2014). Researchers have identified a multitude of ways that the Party-state have been trying to meet the challenges of governing through the Internet: Esarey sees the installation of government accounts on social media as a form of responsive and interactive online governance (Esarey 2015), Han focused on the state-sponsored commentators known as 'fifty-cent armies' (Han 2015), while Repnikova and Fang argued that netizens are now included as thought collaborators in a authoritarian participatory persuasion regime (Repnikova and Fang 2018). Furthermore, while previous research suggested that the state had a passive role in the emerging microblogsphere, that it might be able to exercise censorship, but has 'lost ideational leadership' (Tong and Lei 2013); this has also changed in the past few years. There are now 175,000 official government affairs Weibo accounts, 136,000 of which are official institutional accounts, and 39,000 are accounts owned by government officials (S. Wang 2017). Indeed, increasingly the main propaganda apparatuses of the Party-state has emphasised the need to update their thought work techniques, as this People's Daily Editorial suggests:

\footnotetext{
"In a country with 700 million netizens, the regulators of the Internet will be mocked if their thoughts cannot keep up with the masses, they will be frustrated if they don't have a couple of tricks up their sleeves, they will be constantly worried if they don't have more than one way of dealing with problems, and if they don't achieve good regulatory results they will be constantly criticised by everyone." (People's Daily Editorial 2018)
}

The Editorial went on to suggest that those doing propaganda work must update their repertoire with the demands of the digital age and avoid approaching the masses with the 'same old tone'. Ironically, this article is written in the exact outdated tone and format that it is trying to discourage. Furthermore, the editorial piece still subjects cyber-plurality to blackand-white political labelling: 
We need to be able to differentiate the plethora of opinions on the Internet... Those issues are that academic, we can allow them to flourish, while positively guiding them. Those who are ideologically misguided, we need to be tolerant and seek to conform them. The politically sabotaging issues however, we will have to fight and struggle against with all that we have.

Although a heavy emphasis is placed on self-censorship, the regulations and extent to which content should be censored is often vague as above. This power of uncertainty and monopolising the power of interpretation in the hands of the authority has been demonstrated to be a very effective control strategy (Hassid 2008). This is because the punishment for failing to censor appropriately can be severe: as such, often institutions and websites overcensor themselves, leading to strict crackdowns and swift deletions. When the tension builds between Internet platform censors and its users over issues that do not threaten the Partystate's capacity to rule, however, the presence of official accounts on social media allows Party mouthpieces such as the People's Daily to step in and act as the mediator, thus establishing itself as the voice of reason and guiding authority.

The Party-state's attempt at expanding propaganda work in the cyberspace 'using the language of the netizens' is, therefore, an active attempt to control and transform and subjugate online civic discourse into its official narrative. As a part of the more orderly and subtle public opinion and information management technique, official outlets of information are digitally revamped, government social media accounts are expanded, netizens are invited to join the 'family unit' of their leader and consume practical services exclusive to official channels (Repnikova and Fang 2018). Increasingly, the Party-state also does this by acting as the ultimate authority in mediating online contention, stepping in to conciliate contentious topics appearing on the Chinese Internet.

For this section, I looked at the top twenty public opinion incidents identified by the People's Daily Public Opinion Monitoring Office in 2016, and identified whether they were of a contentious nature. A public opinion incident could be very popular but not contentious, such as China winning the Olympics. An incident was only categorised as contentious if it generated significant amount of controversy and online debate, and, crucially, if it contained contentious elements that positioned netizens in conflict with the authorities. Although data was available for 2017 and 2018, there were not enough samples of contentious events in the following two years. Official media responses related to each event such as People's Daily Editorials were collected and subsequently coded using NVIVO 12, with secondary level coding organising data into themes. 
Table 1 shows an example of how the seven most contentious topics in the top 20 public opinion incidents in 2016 were managed by People's Daily official outlets.

[TABLE 1 HERE] 


\begin{tabular}{|c|c|c|c|c|c|c|}
\hline & Challenge Rumours & $\begin{array}{l}\text { Emphasis On Govt } \\
\text { Rapid Response \& } \\
\text { Action }\end{array}$ & $\begin{array}{l}\text { Emphasise Corporate } \\
\text { Accountability }\end{array}$ & $\begin{array}{l}\text { Emphasise Local } \\
\text { Government } \\
\text { Responsibility }\end{array}$ & $\begin{array}{l}\text { Moralising The } \\
\text { Narrative }\end{array}$ & $\begin{array}{l}\text { Preventing } \\
\text { Mobilisation }\end{array}$ \\
\hline $\begin{array}{l}\text { Lei Yang (Alleged } \\
\text { Police Brutality) }\end{array}$ & $\begin{array}{l}\text { "We need patience to } \\
\text { find the truth... I } \\
\text { believe... the police } \\
\text { will not dare to cover } \\
\text { up brutality nor do } \\
\text { they have a reason to } \\
\text { do so" } 10 \text { May }\end{array}$ & $\begin{array}{l}\text { "Beijing People's } \\
\text { Procuratorate } \\
\text { accepted the case in a } \\
\text { timely fashion and } \\
\text { everyone involved felt } \\
\text { how fair and just the } \\
\text { law is" } 1 \text { June }\end{array}$ & - & - & - & $\begin{array}{l}\text { Public petition } \\
\text { censored }\end{array}$ \\
\hline $\begin{array}{l}\text { Wei Zexi } \\
\text { (Medical Fraud) }\end{array}$ & - & $\begin{array}{l}\text { "The state is now } \\
\text { investigating Baidu... } \\
\text { such rapid responses } \\
\text { show how responsive } \\
\text { the government is to } \\
\text { the people's need and } \\
\text { their sense of } \\
\text { responsibility" } 3 \text { May }\end{array}$ & $\begin{array}{l}\text { "It is not enough for } \\
\text { corporations not to } \\
\text { do evil but they must } \\
\text { bear responsibility for } \\
\text { their actions" } 1 \text { May }\end{array}$ & - & $\begin{array}{l}\text { "People will fall for } \\
\text { medical fraud when } \\
\text { they are clutching at } \\
\text { straws... they need to } \\
\text { give up unrealistic } \\
\text { hopes when faced } \\
\text { with terminal illness" } \\
6 \text { May }\end{array}$ & - \\
\hline Vaccine Scandal & $\begin{array}{l}\text { "Spreading rumours } \\
\text { about fake vaccines } \\
\text { leads to arrests of a } \\
\text { 35-year-old mother" } \\
26 \text { March }\end{array}$ & $\begin{array}{l}\text { "Premier Li Kekang } \\
\text { made important } \\
\text { instructions... } 357 \\
\text { people have been } \\
\text { held accountable } \\
\text { which lets the people } \\
\text { feel how determined } \\
\text { the Party and the } \\
\text { state is in solving this } \\
\text { case" } 23 \text { March }\end{array}$ & $\begin{array}{l}\text { "Marketisation means } \\
\text { it's difficult to control } \\
\text { the vaccines sources } \\
\text { and logistics... some } \\
\text { institutions and } \\
\text { individuals would } \\
\text { partake in illegal } \\
\text { activities for personal } \\
\text { profit" } 25 \text { March }\end{array}$ & $\begin{array}{l}\text { "Local government } \\
\text { cadres must be held } \\
\text { accountable and } \\
\text { should resign" } 28 \\
\text { April }\end{array}$ & $\begin{array}{l}\text { "It's understandable } \\
\text { that the people would } \\
\text { panic after a vaccine } \\
\text { scandal, as they have } \\
\text { no way to tell of } \\
\text { vaccines are real or } \\
\text { fake" } 26 \text { April }\end{array}$ & - \\
\hline
\end{tabular}




\begin{tabular}{|c|c|c|c|c|c|c|}
\hline $\begin{array}{l}\text { Poisonous } \\
\text { Running Tracks } \\
\text { In Schools }\end{array}$ & $\begin{array}{l}\text { "In events that needs } \\
\text { expert knowledge, } \\
\text { scientists... should } \\
\text { help stabilise public } \\
\text { emotions" } 24 \text { June }\end{array}$ & $\begin{array}{l}\text { "The Education } \\
\text { department has a } \\
\text { clear zero-tolerance } \\
\text { attitude to these } \\
\text { problems which } \\
\text { makes us see hope" } \\
27 \text { June }\end{array}$ & $\begin{array}{l}\text { "When schools don't } \\
\text { have enough funds to } \\
\text { satisfy the equipment } \\
\text { needs for government } \\
\text { checks, they opt for } \\
\text { the quick and low } \\
\text { quality option" } 27 \\
\text { June }\end{array}$ & $\begin{array}{l}\text { "Beijing has set a } \\
\text { good example of } \\
\text { positively dealing with } \\
\text { these problems... how } \\
\text { will the other local } \\
\text { governments follow?" } \\
18 \text { June }\end{array}$ & - & - \\
\hline $\begin{array}{l}\text { Yang Gailan } \\
\text { (Murder-Suicide) }\end{array}$ & - & $\begin{array}{l}\text { "After the crime was } \\
\text { discovered the county } \\
\text { government instituted } \\
\text { emergency } \\
\text { procedures, to help } \\
\text { those involved and to } \\
\text { solve the case" } 16 \text { Sep }\end{array}$ & - & $\begin{array}{l}\text { "We have held the } \\
\text { cadres at the county, } \\
\text { township and village } \\
\text { levels accountable" } 16 \\
\text { Sep }\end{array}$ & $\begin{array}{l}\text { "One of the main } \\
\text { reasons accounting } \\
\text { for the tragedy is that } \\
\text { the cadres failed to } \\
\text { actively diffuse } \\
\text { conflicts among the } \\
\text { community... the } \\
\text { family had very little } \\
\text { interactions with the } \\
\text { villagers and had poor } \\
\text { relationships with } \\
\text { most of them" } 16 \text { Sep }\end{array}$ & - \\
\hline Gaokao Reform & $\begin{array}{l}\text { "Public policy } \\
\text { decisions needs to be } \\
\text { laid out carefully } \\
\text { otherwise they will be } \\
\text { misinterpreted by the } \\
\text { public" } 14 \text { May }\end{array}$ & $\begin{array}{l}\text { "Hubei \& Jiangsu } \\
\text { educational } \\
\text { departments have } \\
\text { issued statements to } \\
\text { say there is no } \\
\text { reducing intake } \\
\text { numbers" } 14 \text { May }\end{array}$ & - & - & - & Protest Censored \\
\hline $\begin{array}{l}\text { Anti-Nuclear } \\
\text { Protest }\end{array}$ & - & (1) & - & - & - & $\begin{array}{l}\text { Protest censored, no } \\
\text { direct response - govt } \\
\text { ultimately backed } \\
\text { down }\end{array}$ \\
\hline
\end{tabular}

Table 1. Content management strategies in contentious topics in top 20 public opinion incidents, 2016. Source: People's Daily Online (http://www.people.com.cn/) 
In dealing with public opinion incidents, two main types of strategies can be identified: information management, and information containment. The main containment strategy is censorship. Blanket censorship however, only occurs when contention threatens to lead to mass mobilisation (King, Pan, and Roberts 2013), while the baseline level of censorship applies in most other cases. We can see that in the seven incidents identified, only three incidents prompted blanket bans of mentions of mobilisation attempts (petitions and offline protests). The management strategies, however, are more varied, and can be broadly classified into three further categories: de-escalation, delegation, and depoliticisation. These strategies are examined in more detail below.

\section{Deescalation}

It has been suggested that two types of discourses exist in Chinese society: the top-down official discourse, dominated by traditional media, and the bottom-up civic discourse, existing mostly in the online sphere (Y. Zhao 2008; Ellis, Kent, and Xu 2017). Dominant discourses in mass media 'assumes crucial significance in defining and interpreting certain events use to its advantaged social position and historical social influence' (Stockmann 2013). Meanwhile, rising civic discourses in social media 'empowers marginalised general public to reflect on, resist and deconstruct the top-down dominant frameworks' (Ellis, Kent, and $\mathrm{Xu}$ 2017). Although the two discourses can collaborate and balance each other, when in contentious events, the two discourses are often engaged in conflict and fighting for dominance over each other. Grassroot counter-narratives would emerge during contentious events drawing upon everyday experiences and moral judgements to argue 'risk out of control', while official narratives would seek de-escalation of contention by emphasising stability and 'risk under control' (Y. Wang 2017). A good example of this is the Lei Yang case, where suspected police brutality led to the death of an environmentalist in Beijing. The grassroot narratives centred around how the protagonist (Lei Yang) was an 'unlikely victim', due to the fact that he was well-educated, middle class, and had no prior criminal history or altercation with the police. The anxiety of being subject to random acts of police brutality was acknowledged by the People's Daily, and addressed accordingly:

"People also ask: if we are not like Lei Yang who graduated from a top university in Beijing, if something like this happens to us, will we just disappear into obscurity? ... Citizens should not die a wrongful death and the police should not be accused wrongly either. We need patience... I choose to believe with good intentions that after years of experience, the police will not dare to cover up brutality nor do they have a reason to do so." (People's Daily, 10 May 2016) 
Risk-under-control, de-escalation narratives fall into two further types of accounts: challenging rumours, and emphasising rapid response and action taken by the government. The former account frame the public and netizens as emotional, misled citizens with limited access to reliable information. By contrast, the government, regulatory bodies and experts are framed as the only authoritative and trustworthy sources of information, and are called upon to dispel rumours and myths perpetuated by the unwitting public. For instance, when the public grew concerned over the use of recycled tyres in the making of sports equipment in schools, the People's Daily called for vigilance against 'unscientific rumours':

In events that needs expert knowledge, scientists need to step up and help stabilise public emotions, let the scientific fact dominate the discussion. (Ya 2016)

The official narratives offer emotional sympathy rather than directly engaging with public questions of government accountability and transparency, thus delegitimising any counternarratives in the process. In extreme cases, those who are found to be spreading rumours can be arrested (Z. Wang 2016a).

Parallel to challenging rumours is the emphasis on government rapid response. We can see from Table 1 that emphasis of rapid government action is a standard and consistent management strategy in almost all contentious events, where as other strategies are employed more ad-hoc. Indeed, according to People's Daily statistics for 2017, the response rate for reblogged public opinion incidents from official accounts is $90 \%$, with $42 \%$ rapid response rate (within 24 hours) and 65\% response rate within 72 hours. Different levels of response are reserved for incidents of different severity: local events are usually responded to on a municipal level, while cross-city, provincial level events would also attract attention from the highest institutional ranks. For instance, the Chengdu meteorological office, environmental agency and public health watchdog all responded to the 2017 Chengdu smog at a local level, while the National Health and Family Planning Commission stepped in to deal with a HIV tainted blood scandal at a Zhejiang hospital at a national level (Zhang, Sun, and Liang 2017). For large scale public health events such as the fake vaccine scandal, directives from the highest leadership such as Xi Jinping and Li Keqiang is often quoted (Editorial 2016). In all the cases, narrative emphasis is made on how the government is actively informing, communicating and thus engaging with the public, which is a common political strategy for increasing public political trust (Catterberg and Moreno 2006). Public concern is assuaged by reminding netizens that governments and high ranking officials have been notified of the 
contentious event, thus further de-legitimising any means of action instigated by nonestablished political actors.

\section{Delegation}

If we follow McAdam et al's definition of contentious politics, then the types of contention seen in the Chinese Internet can be seen as transgressive contentions rather than contained contentions (McAdam, Tarrow, and Tilly 2003), whereby the netizens as claimants are nonestablished political actors often employing innovative or forbidden means of action. Online contention in the Chinese cyberspace however, does not only arise from struggles between the authorities and the public (such as the Lei Yang case), but also from discontent over the belief that the authorities have failed to protect the public from other malevolent actors, such as abusive local officials and unethical large corporations. Central government as embodied by the CCP leadership are seen to have a paternalistic duty from protecting its citizens from local and corporate abuse (Miao 2016b), and when an event highlights how the paternalistic protection have failed, attention is shifted to the shortcomings of the current political regime, and contention occurs. In order to de-escalate these types of contention, official narratives often delegate responsibility to corporations and local governments. For instance, when some running tracks in schools were discovered to be made from poisonous material, official narratives were quick to delegate responsibility to both the corporations and schools, blaming the poor profit-seeking moral judgement on both sides. At the same time, emphasis is made on how fast the local government have acted to punish the offenders, while calling for other local governments to follow. Attention is diverted away from counter-narratives that questioned the legal framework for quality control, and government accountability in general, in order to frame the story as 'risk already controlled'. In the case of Yang Gailan, a poor rural woman who committed murder-suicide of her whole family after being denied poverty relief from the local government, the official editorial emphasised the shortcomings of the local cadres, and subverted the counter-narratives that questioned rural-urban inequality, poverty reduction strategies, and the opaqueness of how poverty relief is implemented at the local level.

Part of the delegation strategy reflects the centre-local relationship and political trust in Chinese society. Recent studies have found that many in China continue to hold hierarchical trust towards the government, and although trust in central government is not as high as researchers have previously argued, it is nevertheless higher than local government trust (Li 2016; D. Zhao and Hu 2017). There is evidence that residents use the central government as a shield to fight against power abuse by local government officials, especially in rural areas 
(O'brien and Li 2005). The CCP certainly seeks to capitalise on the public's relatively higher diffuse trust in the central government as it exercises strict control over the media and education system in China (Kennedy 2009). In state-controlled traditional media such as newspapers and televisions, issue-specific criticism against local governments are allowed, and denunciation of local officials in central-led campaigns are common (Chan 2002; Li 2013; Steinhardt 2017). Official narrative of anti-corruption campaigns, for example, are framed around the struggle and determination of the central government battling against local offenders (Shi 2008). Effusive political control, including daily immersion in state-led narratives, in turn encourages the development of hierarchical trust patterns among the Chinese public (Wu and Wilkes 2018). Therefore, it is perhaps unsurprising to see that in many of the risk-under-control narratives, the state emphasises on remedying local government oversights, punishing local culprits, and highlight the swiftness of central government response.

Another part of the delegation strategy shifts the focus of sociopolitical contention to corporate accountability and social responsibility. Similar to the the hierarchal central-local trust, the Chinese public exhibit a much lower trust towards major corporations and companies compared to the central government (42.5\% vs $95.3 \%$ in 2001 according to the World Value Survey) (Ramasamy and Yeung 2009). The private sector at large are seen as amoral and profit-driven (Miao 2016a), whereas the government are expected to be benevolent and give moral consideration to policy decisions (Tong 2011). Official government responses to contentious issues involving large corporations often acknowledge the fact that the public have called for government action, thus fulfilling the role of the ultimate arbiter in contentious situations:

When the [institution implicated] have not yet spoken, when the public are simmering in rage, the truth can only emerge if regulatory bodies [监管部门] respond swiftly and investigate thoroughly (S. Wang 2016a).

In these communications, 'regulatory bodies', or 'relevant departments' [相关部门/有关部 门] are used to denote some form of macro-control that comes from the above, without being specific to the nature or the function of the department entailed. Ultimately the purpose of these communications is to reassure and strengthen the 'risk-under-control' narratives in order to demobilise contention. 


\section{Depoliticisation}

In recent years, the Party-state have increasingly focused their efforts in promoting certain types of acceptable debates online, namely moral and value debates, while discouraging debates on political issues and reframing issues of sociopolitical natures into moral controversies. According to the 2017 Public Opinion Monitoring Report, public opinion incidents that are of a social and moral nature should be welcomed, as they tend to distract public attention away from more sensitive topics such as economic, military and political issues (Hua, Canliang, and Pan 2018). Indeed, it has been noted that the state has allowed protests in certain circumstances when they provide useful information to the state about citizen grievances, and when the participants are willing to pursue weaker, non destabilising strategies (Lorentzen 2017). In the past few years there has been a noticeable shift in public opinion incidents that centre around moral controversies, protection of disadvantaged groups, scams, and ideological conflicts. Labour conflicts and class actions that have the potential to generate collective action have been in decline. As public attention on social issues are likely to wax and wane as time progresses, they are not seen as particularly threatening by the state. The report is also confident in the response rate and efficiency of official government accounts in dissipating any tension surrounding social incidents (Hua, Canliang, and Pan 2018). As a part of the deescalating and managing of online contention, therefore, it is necessary to reframe and redefine online conflicts into moral issues, rather than political issues. In doing so, again the focus of the contention is shifted from structural causes to individual causes, which precludes any criticisms against the regime and prevents any potential mobilisations. For instance, in the Yang Gailan case, the narrative focused on the poor family's social exclusion from the village and assigned superficial blame on local cadres who did not realise such exclusion would lead to tragedy:

We learned that the Yang family had a fraught relationship among themselves with many conflicts. They did not get along with their neighbours and did not involve themselves in the village. Although the local cadres were aware of this, they did not pay sufficient attention to the matter, and did not help to resolve the conflict. (Z. Wang 2016b)

Out of the four 'lessons' identified in the murder-suicide case, three were focused on the 'special circumstances' of the Yang family, i.e., that it was not a harmonious family and had strained neighbourhood relationships. Only a cursory mention is made of how poor relief is administered at the ground level and again the emphasis was made on how the local cadre 
'overlooked' the special circumstances of the Yang family and was not able to help them, rather than on discussions of more deep-seated structural issues.

Similarly in the Wei Zexi case, where a college student died after receiving questionable and unsuccessful treatment for sarcoma from a hospital he had found promoted on the search engine Baidu, the People's Daily published an article where the focal point of discussion was whether people should 'grasp at straws' when faced with a terminal diagnosis, and whether it was wise to have 'unrealistic hopes' (Bai 2016). This moralising narrative, which essentially blamed victims of medical fraud for their own fates, was met with widespread backlash. In the social media discussion that ensued, netizens pointed out that the contentious issue with Wei Zexi lies not in his decision to pursue questionable treatment, but the fact that he chose the treatment after careful research, but the information presented to him by domestic search engine Baidu was biased and unreliable. One netizen wrote:

The hospital ranked first on Baidu, it was listed as a First Tier hospital, the treatment was advertised by China Central Television, and the doctor had numerous awards... If the hospital was as described and still his treatment was unsuccessful, then we can't blame anyone. But everything was a lie. The ranking on Baidu was paid for, the hospital department was outsourced [to private contractors], the treatment was obsolete, and many of the doctor's awards and titles are fake. And then you tell us we have to be calm when faced with life and death? That's fucking stupid. (Zhihu 2016)

Although some also voiced concerns over how private healthcare providers are regulated, the main thrust of the grievance were aimed at Baidu's immoral profit-seeking behaviour. Soon after, the People's Daily published another editorial that emphasised the need for better corporate social responsibility, and announced that more stringent regulations on information provision are now in place (S. Wang 2016b). Again, the official narrative appear sympathetic towards the public grievances and stress that the risks are now under control through prompt response from the higher authorities, thus precluding any further contention or mobilisation.

\section{Digital United Front}

Another important mechanism in the guidance of public opinion is the United Front department, which was revived in the late 1970s in response to the challenges arising from China's transition to market economy and a more pluralistic society. This is particularly 
important in ensuring hegemony, which, according to Gramsci, is achieved when a state does not rely on coercion because it is also supported by civil society's consent and its subjects accept their domination as legitimate. This legitimacy is then known as "common sense" (Simon 2015). Leadership of the governing body must be reflected in national popular appeals that can subsume narrow economic or social interests, and united front work is the critical tool to achieve this (Groot 2004). The United Front Work Department (UFWD), whose main role is to manage and ensure a supportive relationship between extra-Party elites such as academics, social and commercial elites, is now a key player in sustaining CCP's claim to a consultative democracy.

This department has been given renewed priority and focus under Xi Jinping (R. Wang and Groot 2018).In 2015 the CCP issued The Proposed Regulations of the United Front Work of the Chinese Communist Party, and Xi made a further speech at the CCP United Front Work Conference in May 2015, emphasising that

We have to increase online interaction and offline communication with representative members from the new media, and persuade them to use positive energy to clean the cyberspace and sing the main melody.

The social responsibility of the Internet platforms and the destabilising potential of the Internet were further stressed by the People's Daily Public Monitor Office:
"Some might think that Internet platforms are neutral content deliveries, and we should not ask too much social responsibility of them. However, as a social product, with such a large user base, Internet platforms must have higher social responsibility than other Internet companies... the Internet is the biggest variable during social transitions, as it can challenge the market and social order, and create anxieties in the social mood. How to control this variable needs the collective effort of the platform provider, beneficiaries, and the government." (Hua, Canliang, and Pan 2018)

In another editorial, People's Daily noted that online propaganda work should be directed at two types of people: the opinion leaders, as they are key 'social influencers' hence can play an instrumental role in disseminating the propaganda work; and the youth, who are easily influenced by 'outside forces' and must be 'guided properly' (People's Daily Editorial 2018). Thus, social influencers, such as the CEO of Zhihu, popular Weibo and Wechat bloggers and Internet writers were invited to attend study meetings organised by the UFWD (Pengpai 
2018). Attendees were taken to patriotic education bases and asked to study Xi Jinping Thought and take seminars on CCP theory. At the end of the three day study meeting, attendees were asked to leave reflections on how they found the experience. The conforming comments echoing Party lines subsequently published are particularly illuminating:

Internet writers of the new era has been given the task of ideological dissemination and we must be aware of different ideological camps. We have to create protagonists with the right kind of patriotic values so we can guide our readers, and minimise negative voices. - Cyber-fiction writer He Changzai, member of the CPPCC

We must take up more social responsibility and contribute more towards the building of a clean and purified cyberspace. - Zhou Yuan, CEO of Zhihu, member of the CPPCC

Many of these social influencers, such as the CEO of Zhihu, are also members of the National Committee of the Chinese People's Political Consultative Conference (CPPCC), which is a political advisory body mainly containing non-CCP delegates from various social, political, commercial and religious organisations. This echoes the attempt made by the CCP to incorporate economic elites into the Party apparatus through organisations such as CPPCC, so that they would have vested interests in the Chinese state just like political elites (M. Chen 2015; J. Chen and Dickson 2010). Thus, the CCP has ensured that cyber opinion leaders have been incorporated into the wider propaganda and narrative-building network, to make sure that public opinion can indeed be wielded as 'a tool for mainstream political institutions rather than individual opinion leaders online' (Hua, Canliang, and Pan 2018).

\section{Conclusion}

Just like any feature of the Chinese political system, Internet governance in China is flexible and adaptive (Heilmann and Perry 2011). Indiscriminate and stringent negative censorship risks serious backlash among the netizens and traditional forms of preaching propaganda has been shown to be ineffective in the cyberspace. In a repressive political environment such as China, minor incidents have the potential to catch the public's attention and spread like wildfire online, due to 'generalised anger that has built up over time' (Fewsmith 2008). In order to maintain a 'legible and predictable society' (Creemers 2017), participatory censorship and narrative shaping have become crucial content control strategies, along with 
the incorporation of digital elites into political elites. The space for contention and dissent online has not only narrowed but also transformed, as the Party-state allows and even encourages certain types of socio-moral contention in line with its ideological goals. Any other types of contention, apolitical or otherwise, are delegitimised. Grassroot contentious narratives, therefore, must fit within the grander official narrative in order to survive and be heard, and often have to appeal to the central-level institutions and agencies to act as the ultimate arbiter when they come into conflict with local censors, effectively calling upon a kind of paternalistic protection from the Party-state. On the one hand, this strengthens the Party-state's claim to legitimacy as the ultimate moral authority in Chinese society, on the other hand, this weakens the legitimacy and power of the intermediary institutions such as local agencies and authorities who have been tasked with the day-to-day decisions of cyber governance. This has laid the foundation for the simplification of politics which in turn could lead to a rise in populist sentiments in the cyberspace that could be potentially explosive when interacted with its foreign counterparts in the current global political climate.

Abts, Koen, and Stijn van Kessel. 2015. Populism. International Encyclopedia of Social \& Behavioral Sciences. Second Edition. Elsevier. doi:10.1016/B978-0-08-097086-8.931027.

Andreas, Joel, and Yige Dong. 2017. “4 'Mass Supervision' and the Bureaucratization of Governance in China." To Govern China: Evolving Practices of Power. Cambridge University Press, 123.

Bai, Jianfeng. 2016. “人民日报不吐不快：魏则西留下的生命考题 [People's Daily: the Question Left by Wei Zexi].” People's Daily, May 6. http://opinion.people.com.cn/n1/2016/0506/c1003-28329021.html.

Bamman, D, and B O'Connor. 2012. "Censorship and Deletion Practices in Chinese Social Media." First Monday 17 (March).

Beijing Internet Association. 2015. "Strengthening Self Discipline and Purifying the Cyberspace.” Beijing Internet Association. January 27. http://www.baom.com.cn/201501/27/content 13519.htm.

Brady, Anne-Marie M. 2009. Marketing Dictatorship: Propaganda and Thought Work in Contemporary China. Rowman $\backslash \&$ Littlefield.

Brady, Anne-Marie M. 2012. China's Thought Management. Routledge.

Catterberg, Gabriela, and Alejandro Moreno. 2006. "The Individual Bases of Political Trust: Trends in New and Established Democracies." International Journal of Public Opinion Research 18 (1). Oxford University Press: 31-48.

Chan, Alex. 2002. "From Propaganda to Hegemony: Jiaodian Fangtan and China's Media Policy." Journal of Contemporary China 11 (30): 35-51. doi:10.1080/10670560120091138.

Chase, Michael S, and James C Mulvenon. 2002. You"Ve Got Dissent! Chinese Dissident Use of the Internet and Beijing"S Counter-Strategies. Rand Corporation. 
https://books.google.com/books?hl=en\&lr=\&id=9_01DWdvdMIC\&oi=fnd\&pg=PR5\&d $\mathrm{q}=$ youve + got + dissent\&ots=bK-p6KWvZh\&sig=XZK37fGDPFyT_YjpgVlscnUTaD4.

Chen, Jie, and Bruce J Dickson. 2010. Allies of the State: China's Private Entrepreneurs and Democratic Change. Harvard University Press.

Chen, Minglü. 2015. "From Economic Elites to Political Elites: Private Entrepreneurs in the People's Political Consultative Conference.” Journal of Contemporary China 24 (94). Taylor \& Francis: 613-27.

Cheung, Anne SY. 2005. "The Business of Governance: China's Legislation on Content Regulation in Cyberspace." NYUJ Int'l. L. \& Pol. 38. HeinOnline: 1.

China Internet Illegal Reporting Centre. 2018. "Internet Reporting Outcomes in Feburary 2018." 12377. March 27. http://www.12377.cn/txt/2018-03/27/content 40266832.htm.

Creemers, Rogier. 2017. "Cyber China: Upgrading Propaganda, Public Opinion Work and Social Management for the Twenty-First Century." Journal of Contemporary China, February. Routledge, 1-16. doi:10.1080/10670564.2016.1206281.

Editorial. 2016. “李克强批示非法疫苗案：失职渎职 绝不姑息 [Li Keqiang on Illegal Vaccines: We Will Not Pardon Those Who Neglected Their Duties].” People's Daily, March 23. http://health.people.com.cn/n1/2016/0323/c398004-28221524.html.

Ellis, Katie, Mike Kent, and Jian Xu. 2017. Chinese Social Media: Social, Cultural, and Political Implications. Routledge.

Endeshaw, Assafa. 2004. "Internet Regulation in China: the Never-Ending Cat and Mouse Game.” Information \& Communications Technology Law 13 (1). Taylor \& Francis: 4157.

Esarey, Ashley. 2015. "Winning Hearts and Minds? Cadres as Microbloggers in China." Journal of Current Chinese Affairs 44 (2): 69-103.

Esarey, Ashley, and Qiang Xiao. 2011. "Digital Communication and Political Change in China." International Journal of Communication, February, 1-22. http://ijoc.org/index.php/ijoc/article/viewFile/688/525.IJOC_SequentialGrid_20100311.

Espejo, Paulina Ochoa. 2017. "Populism and the Idea of the People." In Populism and the Idea of the People, edited by Cristóbal Rovira Kaltwasser, Paul Taggart, Paulina Ochoa Espejo, and Pierre Ostiguy, 1:1-24. Oxford University Press. doi:10.1093/oxfordhb/9780198803560.013.30.

Fewsmith, Joseph. 2008. "An Anger-Venting Mass Incident Catches the Attention of China's Leadership." China Leadership Monitor 26: 1-10.

Groot, Gerry. 2004. Managing Transitions: the Chinese Communist Party, United Front Work, Corporatism and Hegemony. Routledge.

Han, Rongbin. 2015. "Manufacturing Consent in Cyberspace: China's" Fifty-Cent Army"."

Hartford, Kathleen. 2000. "Cyberspace with Chinese Characteristics." Current History 99 (638). Current History, Inc.: 255.

Hassid, Jonathan. 2008. "Controlling the Chinese Media: an Uncertain Business." Asian Survey 48 (3). University of California Press Journals: 414-30.

He, Baogang, and Mark E Warren. 2011. "Authoritarian Deliberation: the Deliberative Turn in Chinese Political Development." Perspectives on Politics 9 (2). Cambridge University Press: $269-89$.

Heilmann, Sebastian, and Elizabeth J Perry. 2011. Mao's Invisible Hand: the Political Foundations of Adaptive Governance in China. Harvard University Asia Center Cambridge, MA. 
Hua, Xinzhu, Liao Canliang, and Yufeng Pan. 2018. “2017年中国互联网與论分析报告 [2017 Internet Public Opinion Monitoring Report.” Reports on Special Subjects.

Kennedy, John James. 2009. "Maintaining Popular Support for the Chinese Communist Party: the Influence of Education and the State-Controlled Media." Political Studies 57 (3). SAGE Publications Sage UK: London, England: 517-36.

King, Gary, Jennifer Pan, and Margaret E Roberts. 2013. "How Censorship in China Allows Government Criticism but Silences Collective Expression.” American Political Science Review 107 (2). Cambridge University Press: 326-43.

Lessig, Lawrence. 2009. Code: and Other Laws of Cyberspace. ReadHowYouWant. com.

Lewis, Orion A. 2013. "Net Inclusion: New Media's Impact on Deliberative Politics in China." Journal of Contemporary Asia 43 (4). Taylor \& Francis: 678-708. doi:10.1080/00472336.2013.769387.

Li, Lianjiang. 2013. "The Magnitude and Resilience of Trust in the Center: Evidence From Interviews with Petitioners in Beijing and a Local Survey in Rural China." Modern China 39 (1). Sage Publications Sage CA: Los Angeles, CA: 3-36.

Li, Lianjiang. 2016. "Reassessing Trust in the Central Government: Evidence From Five National Surveys." The China Quarterly 225. Cambridge University Press: 100-121.

Liang, Bin, and Hong Lu. 2010. "Internet Development, Censorship, and Cyber Crimes in China." Journal of Contemporary Criminal Justice 26 (1). SAGE Publications Sage CA: Los Angeles, CA: 103-20. doi:10.1177/1043986209350437.

Lorentzen, Peter. 2017. "Designing Contentious Politics in Post-1989 China." Modern China 43 (5). SAGE Publications Sage CA: Los Angeles, CA: 459-93.

MacKinnon, Rebecca. 2011. "China's "Networked Authoritarianism"." Journal of Democracy 22 (2): 32-46. doi:10.1353/jod.2011.0033.

McAdam, Doug, Sidney Tarrow, and Charles Tilly. 2003. "Dynamics of Contention." Social Movement Studies 2 (1). Taylor \& Francis: 99-102.

Meng, B. 2010. "Moving Beyond Democratization: a Thought Piece on the China Internet Research Agenda." International Journal of Communication.

Miao, Y. 2016a. Being Middle Class in China: Identity, Attitudes and Behaviour. Taylor \& Francis.

Miao, Ying. 2016b. "The Paradox of Middle-Class Attitudes in China: Democracy, Social Stability, and Reform." Journal of Current Chinese Affairs 45 (1): 169-90.

Mudde, Cas. 2017. "Populism: an Ideational Approach." In The Oxford Handbook of Populism, edited by Cristóbal Rovira Kaltwasser, Paul Taggart, Paulina Ochoa Espejo, and Pierre Ostiguy, 1:1-26. Populism. Oxford University Press. doi:10.1093/oxfordhb/9780198803560.013.1.

O'brien, Kevin J, and Lianjiang Li. 2005. "Popular Contention and Its Impact in Rural China." Comparative Political Studies 38 (3). Sage Publications Sage CA: Thousand Oaks, CA: 235-59.

Pengpai. 2018. “知乎CEO周源、咪蒙等52名网络人士出席统战部理论研讨班 [Zhihu CEO Zhouyuan Et Al Attending Study Meetings Organised by United Front Work Department].” ThePaper.Cn. March 26. http://www.thepaper.cn/newsDetail_forward_2043049.

People's Daily Editorial. 2018. “网络治理关键是凝聚人心 [the Key to Managing the Internet Is to Grab People's Hearts]." Peoples Daily Public Opinion Monitor. Accessed May 10. http://yuqing.people.com.cn/n1/2018/0502/c209043-29960496.html. 
Pieke, Frank N. 2012. "The Communist Party and Social Management in China." China Information 26 (2). SAGE Publications Sage UK: London, England: 149-65.

Ramasamy, Bala, and Mathew Yeung. 2009. "Chinese Consumers' Perception of Corporate Social Responsibility (CSR).” Journal of Business Ethics 88 (1). Springer: 119-32.

Repnikova, Maria, and Kecheng Fang. 2018. "Authoritarian Participatory Persuasion 2.0: Netizens as Thought Work Collaborators in China." Journal of Contemporary China, April. Routledge, 1-17. doi:10.1080/10670564.2018.1458063.

Schlæger, Jesper. 2013. E-Government in China: Technology, Power and Local Government Reform. Vol. 34. Routledge.

Schlæger, Jesper, and Min Jiang. 2014. "Official Microblogging and Social Management by Local Governments in China." China Information 28 (2). SAGE Publications Sage UK: London, England: 189-213. http://journals.sagepub.com/doi/full/10.1177/0920203X14533901.

Shambaugh, D. 2007. "China's Propaganda System: Institutions, Processes and Efficacy." The China Journal. doi:10.1086/tcj.57.20066240;issue:issue:10.2307/i20066237;subPage:string:Access.

Shi, Tianjian. 2008. "China: Democratic Values Supporting an Authoritarian System.” How East Asians View Democracy. Columbia University Press New York, 209-37.

Shirk, Susan L. 2011. Changing Media, Changing China. Oxford University Press.

Simon, Roger. 2015. Gramsci's Political Thought: an Introduction. Lawrence \& Wishart.

Sina Weibo. 2017. “新浪微博公开招募千名监督员 [Weibo Is Now Recruiting for Content Supervisors].” Sina. September 27. http://news.sina.com.cn/o/2017-09-27/doc-ifymeswe0340619.shtml.

Sina Weibo. 2018. “微博监督员2018年3月6日微博 [Weibo Post by Weibo Supervisors Account on 6 March 2018]." Sina Weibo. March 16. https://m.weibo.cn/status/4218272393738217.

Sohmen, Philip. 2001. "Taming the Dragon: China's Efforts to Regulate the Internet." Stanford Journal of East Asian Affairs 1 (1): 17-26.

Steinhardt, H Christoph. 2017. "Discursive Accommodation: Popular Protest and Strategic Elite Communication in China." European Political Science Review 9 (4). Cambridge University Press: 539-60.

Stockmann, Daniela. 2013. Media Commercialization and Authoritarian Rule in China. Cambridge University Press.

Svensson, Marina. 2014. "Voice, Power and Connectivity in China's Microblogosphere: Digital Divides on SinaWeibo" 28 (2): 168-88. doi:10.1177/0920203X14540082.

Tang, Wenfang. 2016. "Populist Authoritarianism." In Populist Authoritarianism, 152-66. Chinese Political Culture and Regime Sustainability. Oxford University Press. doi:10.1093/acprof:oso/9780190205782.003.0009.

Tarrow, Sidney G. 2011. Power in Movement: Social Movements and Contentious Politics. Cambridge University Press.

Tilly, Charles. 2015. Popular Contention in Great Britain, 1758-1834. Routledge.

Tong, Yanqi. 2011. "Morality, Benevolence, and Responsibility: Regime Legitimacy in China From Past to the Present." Journal of Chinese Political Science 16 (2). Springer: 141-59.

Tong, Yanqi, and Shaohua Lei. 2013. "War of Position and Microblogging in China." Journal of Contemporary China 22 (80). Taylor \& Francis: 292-311. doi:10.1080/10670564.2012.734084. 
Tsai, Wen-Hsuan. 2016. “How 'Networked Authoritarianism' Was Operationalized in China: Methods and Procedures of Public Opinion Control." Journal of Contemporary China 25 (101). Taylor \& Francis: 731-44. doi:10.1080/10670564.2016.1160506.

Wacker, Gudrun. 2003. "The Internet and Censorship in China." In China and the Internet, 70-94. Routledge.

Wang, Ray, and Gerry Groot. 2018. "Who Represents? Xi Jinping's Grand United Front Work, Legitimation, Participation and Consultative Democracy." Journal of Contemporary China, February. Taylor \& Francis, 1-15. doi:10.1080/10670564.2018.1433573.

Wang, Shichuan. 2016a. “人民日报评“魏则西之死”：如果丢掉责任，企业还能走多远？ [the People's Daily on the Death of Wei Zeixi: if Corporations Have No Responsibility, How Far Can They Go?]." People's Daily, May 1. http://www.thepaper.cn/baidu.jsp?contid $=1463621$.

Wang, Shichuan. 2016b. “人民时评：别把企业社会责任当口香糖 [the People‘S Daily Editorial: Don'T Treat Corporate Social Responsibility Like Chewing Gum].” People's Daily, June 28. http://cpc.people.com.cn/pinglun/n1/2016/0628/c78779-28502439.html.

Wang, Shichuan. 2017. “2016年中国移动與论场研究报告 [2016 Report on Chinese Public Opinion Spheres].” Peoples Daily Public Opinion Monitor. July 13. http://yuqing.people.com.cn/n1/2017/0713/c209043-29402618.html.

Wang, Yang. 2017. "Framing Food Safety Issues in China: the Negotiation Between 'Official Discourse' in Newspapers and "Civil Discourse"on Weibo." In Chinese Social Media, 77-91. Routledge.

Wang, Zhengqi. 2016a. “西安一35岁妈妈转发问题疫苗假信息被拘留5天 [35 Year Old Mother Is Detained for 5 Days for Spreading Rumours About Fake Vaccines]." People's Daily, March 26. http://society.people.com.cn/n1/2016/0326/c1008-28228340.html.

Wang, Zhengqi. 2016b. “甘肃通报“杨改兰特大故意杀人案”调查处置情况 [Guansu Report on the Investigation of the Murder-Suicide of Yang Gailan]." People's Daily, September 16. http://society.people.com.cn/n1/2016/0916/c1008-28718648.html.

Wright, Joss. 2014. "Regional Variation in Chinese Internet Filtering." Information, Communication \& Society 17 (1). Taylor \& Francis: 121-41.

Wu, Cary, and Rima Wilkes. 2018. "Local-National Political Trust Patterns: Why China Is an Exception." International Political Science Review 39 (4). SAGE Publications Sage UK: London, England: 436-54.

Xiao, Qiang. 2011. "The Rise of Online Public Opinion and Its Political Impact." Changing Media, Changing China, 202-24.

Ya, Ting. 2016. “人民日报民生观: 问题跑道的锅别让轮胎背 [Recycled Tyres Are Not Responsible for Problem Running Tracks].” People's Daily, June 24. http://opinion.people.com.cn/n1/2016/0624/c1003-28473732.html.

Yang, Dali L. 2001. "The Great Net of China." Harvard International Review 22 (4). Harvard International Relations Council: 64.

Yang, G. 2017. "Killing Emotions Softly: the Civilizing Process of Online Emotional Mobilization." Communication \& Society 40: 75-104.

Yang, Guobin. 2014. "Political Contestation in Chinese Digital Spaces: Deepening the Critical Inquiry." China Information 28 (2). SAGE PublicationsSage UK: London, England: 145-67. doi:10.1177/0920203X14539910.

Yu, Haiqing. 2009. Media and Cultural Transformation in China. Routledge. 
Zhang, Li, Xin Sun, and Zhuohao Liang. 2017. “第一季度全国政务與情回应指数评估报告 [First Quarter Report on China Public Opinion Reponse Index].” Peoples Daily Public Opinion Monitor. May 2. http://yuqing.people.com.cn/n1/2017/0502/c20904329248623.html.

Zhao, Dahai, and Wei Hu. 2017. "Determinants of Public Trust in Government: Empirical Evidence From Urban China." International Review of Administrative Sciences 83 (2). SAGE Publications Sage UK: London, England: 358-77.

Zhao, Yuezhi. 2008. Communication in China: Political Economy, Power, and Conflict. Rowman \& Littlefield Publishers.

Zheng, Yongnian. 2007. Technological Empowerment: the Internet, State, and Society in China. Stanford University Press.

Zhihu. 2016. “如何看待人民日报刊文谈魏则西事件：遇到绝症，应坦然面对生死？

[What'S Your Opinon on the People“S Daily"s Article on Wei Zexi?].” Zhihu. May 7. https://www.zhihu.com/question/45543408/answer/99268106.

Zhihu. 2018. “知乎关于加大整治违法有害信息的公告[Zhihu'S Announcement on Increasing Censorship on Illegal and Harmful Content].” Zhihu. March 2. https://zhuanlan.zhihu.com/p/34178151.

2009. "The Power of the Internet in China," June. Columbia University Press, 320.

http://books.google.co.uk/books?id=91u5ccRbuzoC\&printsec $=$ frontcover\&dq $=$ intitle:The + Power + of + the + Internet + in + China\&hl $=\& c d=1 \&$ source $=$ gbs_api. 